\title{
A review of the Tom Rozwadowski medal
}

\author{
HW Ittmann* \\ Received: 25 January 2013; Revised: 19 March 2013; Accepted: 22 March 2013

\section{Dedication to Emeritus Professor Theodor Stewart} \\ Theo Stewart is one of the prominent operations researchers in South Africa and arguably \\ the most well-known internationally. He has contributed significantly to the discipline of OR \\ throughout his career. His research contributions to the Multiple Criteria Decision Analysis \\ field possibly constitute his greatest achievements amongst many. Not only is Theo widely \\ respected for his research but also his work of an applied nature. I was privilege to start \\ my OR career under his guidance and worked directly with him for more than ten years at \\ the CSIR. It is indeed an honour to dedicate this to a friend, and mentor for many years, \\ someone who's dedication to OR will remain a legacy.
}

\begin{abstract}
The Tom Rozwadowski (TR) medal is the most prestigious award of the Operations Research Society of South Africa (ORSSA). The award, first presented in 1971, was established in honour of one of ORSSA's founding members. Initially the medal was to be presented to a member of the society for a paper of most outstanding merit, but the rules were subsequently adapted and currently the medal is awarded to the best paper published during the previous calendar year. This review endeavours to present an analysis of all the award winning papers since its inception. The aim is three-fold, namely: to present a historical review, to detect any trends within Operations Research (OR) in South Africa and to present a view of OR in the country. The analysis indicates that these award-winning papers are very diverse in nature, which certainly epitomises OR in South Africa, but the sample is small and thus not representative enough to be used to draw strict conclusions about the evolution of OR in South Africa. The papers, in general, exhibit originality, quality and clarity of exposition while there is clear interaction between theory and practice.
\end{abstract}

Key words: Tom Rozwadowski medal, History of OR in South Africa, practical case studies.

\section{Introduction and background}

The Operations Research Society of South Africa (ORSSA) was formally founded in November 1969 (Geldenhuys \& Rudolph 1999) having had its roots in the mining industry, dating back to the early fifties (Fatti 1988). Ever since its formation the society

*(Fellow of the Operations Research Society of South Africa), Research Associate, Institute of Transport and Logistics Studies (ITLS) (Africa), University of Johannesburg, 2006, South Africa, email: hittmann01@gmail.com. 
has been fairly active through the publication of a newsletter, abstracts of an annual conference as well as the bi-annual publication of a journal, ORiON. The latter initiative only started in 1985 and since then the journal has developed into a world-class publication.

A tragic event in 1970 prompted the establishment of an award, the Tom Rozwadowski (TR) medal, to individual members of the society. This was in line with a practice followed by other societies elsewhere in the world. Similar awards are, inter alia, made by the Operational Research Society of the UK and the Institute for Operations Research and the Management Sciences (INFORMS) of the USA, two of the larger international societies. In the case of the OR Society, the award is the Goodeve medal, named in memory of Sir Charles Goodeve, one of the founders and pioneers of civilian Operational Research (OR Society 2013). This medal is awarded "in recognition of the most outstanding contribution to the philosophy, theory or practice of OR published in the Journal of the OR Society (JORS) or OR Insight (ORI), within the relevant year." It is interesting to note that only papers published in the two journals of that society are considered for the award. In the case of INFORMS, the Lanchester prize is awarded "for the best contribution to operations research and the management sciences published in English in the past three years. The prize includes a commemorative medallion and a cash award. The award is given each year at the INFORMS National Meeting, if there is a suitable recipient" (INFORMS 2013a). The Lanchester prize is one of numerous INFORMS prizes and awards, but possibly resembles the TR medal and the Goodeve medal the closest.

A few overview papers have been published on OR in South Africa. Fatti (1988) gave a view on the (then) current practice of OR in South Africa while an update was presented by Stewart (1995). Hearne $(1994 ; 1999)$ emphasised the environmental applications of OR. A short history of ORSSA, and its activities, was presented by Ittmann \& Yadavalli (2010). The emphasis and focus of this paper, however, is on the publications that received the TR medal. This paper presents a historical review of the TR medal winners, to detect any trends within OR in South Africa and to present a view of South African OR. It is now customary to announce the winner of this award at the annual conference of ORSSA while this announcement, with a short summary of the winning paper, appears in an edition of a subsequent ORSSA newsletter. In addition, the TR medal "Hall of Fame," with all the winning papers and authors, is available on the ORSSA website (ORSSA 2013). No review or analysis have been performed on the work leading to the current TR medal winners and the associated publications. The time period selected for this analysis has no significance. However, the need to record this history of ORSSA cannot be disputed.

The remainder of this paper is structured as follows. A brief summary is provided around the person, Tom Rozwadowski. The complete list of TR medal recipients is given as well as a few of the more important criteria used in deciding on the medal winner. Some general comments concerning the medal are then given as well as an analysis of the institutions of the winners, the journals within which the winning papers were published, the techniques used, the application areas and facts about the number of times some individuals have won the award. The next section provides an outline of the work of the initial four winning publications and thereafter very brief summaries of each of the publications. Finally information is provided on additional, including international, recognition for award winning papers. The conclusion summarizes the major findings of the analysis. 


\section{Tom Rozwadowski medal}

General information on the TR medal is discussed in the following subsections.

\subsection{Tom Rozwadowski - the person}

During the period leading up to the formation of ORSSA, various OR groups were established across the country. The Johannesburg OR Group was one of these under the chairmanship of Tom Rozwadowski who was the driving force behind this group and also one of the founding members of ORSSA. From Polish decent, he was a very dynamic and enthusiastic figure promoting OR. After completing his MSc thesis at the University of the Witwatersrand, he, his wife and two children went to the USA where he was to conduct research at Control Data Corporation Headquarters in Minneapolis. During October 1970 news was received of the death of the entire family. They had spent a weekend outside Minneapolis, where Tom was to give a talk on South Africa at a Catholic Church in Annadale, Minnesota. There they had been put up for the night in a cottage as guests of the church. The gas central heating had a leaking pipe and the next morning they were all found asphyxiated. Before his untimely death, Tom was already preparing his PhD. In the OR field, he specialised in optimisation techniques, whilst also having a good knowledge of inventory control, game theory, simulation and dynamic programming (ORSSA 1971).

In consultation with his South African relatives, it was agreed that ORSSA would establish the TR medal in his memory. At the Annual General Meeting of ORSSA in 1970 it was announced that the TR Medal would be made available for a paper of outstanding merit by a member of ORSSA (ORSSA 1971).

\section{$2.2 \quad$ Recipients}

For completeness the list of recipients of the TR medal from 1971 until 2012 is given in Tables 1 and 2 . In each case only the recipients of the medal (i.e. those that were ORSSA members, at the time of the publication date of the award winning paper) are listed. In nine cases there were co-authors that were not members of ORSSA and in these cases the paper reference is given for ease of identification. The full details of all the recipient publications are given in the list of references.

\subsection{Important rules}

Initially the medal was to be presented to a member of ORSSA for "a paper of outstanding merit" and it was only later that formal rules where established. The rules have been changed and refined over the years and the current full set of rules is available on the ORSSA website (ORSSA 2013). The following rules are, however, of interest:

- Contributions of an OR nature published in journals of international standing during the previous calendar year are eligible for consideration.

- One or more of the following criteria may be used as a basis for making the award:

- originality, 


\begin{tabular}{|c|c|c|c|}
\hline Year & Recipient(s) & Institution & Title of paper/document \\
\hline 1971 & GJ Rudolph & $\begin{array}{l}\text { Department of Posts and Tele- } \\
\text { graphs }\end{array}$ & Optimal Mail Sorting Policy \\
\hline 1976 & BJK Smith & $\begin{array}{l}\text { Consolidated Diamond Mines } \\
\text { (CDM) of South West Africa Ltd. }\end{array}$ & $\begin{array}{l}\text { A Medium Term Mine Planning System for } \\
\text { a Beach Diamond Deposit }\end{array}$ \\
\hline 1977 & $\begin{array}{ll}\text { PJ Vermeulen } \\
\text { and DCJ de } \\
\text { Jongh }\end{array}$ & $\begin{array}{l}\text { University of Pretoria and Coun- } \\
\text { cil for Scientific and Industrial Re- } \\
\text { search }\end{array}$ & $\begin{array}{l}\text { Parameter Sensitivity of the 'Limits to } \\
\text { Growth' world model }\end{array}$ \\
\hline 1978 & $\begin{array}{l}\text { TJ Stewart and } \\
\text { HW Ittmann }\end{array}$ & $\begin{array}{l}\text { Council for Scientific and Industrial } \\
\text { Research }\end{array}$ & $\begin{array}{l}\text { Two-Stage Optimization in a Transporta- } \\
\text { tion Problem }\end{array}$ \\
\hline 1979 & JS Wolvaardt & University of South Africa & 'n Teorie van die aanbod van steenkool \\
\hline 1980 & TJ Stewart & $\begin{array}{l}\text { Council for Scientific and Industrial } \\
\text { Research }\end{array}$ & Contributions to Search Theory \\
\hline 1981 & LP Fatti & University of the Witwatersrand & $\begin{array}{l}\text { Optimal Smoothing of Demand for Indus- } \\
\text { trial Gas }\end{array}$ \\
\hline 1982 & PJS Bruwer & North-West University & $\begin{array}{l}\text { Bydraes tot Model Ontwikkeling ten einde } \\
\text { gerekenariseerde stelsels se werkverrigting } \\
\text { te evalueer }\end{array}$ \\
\hline 1983 & JC Lawton & Mobil Oil & A Purchasing Problem \\
\hline 1984 & TJ Stewart & $\begin{array}{l}\text { Council for Scientific and Industrial } \\
\text { Research }\end{array}$ & $\begin{array}{l}\text { Contributions to Multiple Criteria Deci- } \\
\text { sion Making (MCDM) }\end{array}$ \\
\hline 1985 & $\begin{array}{l}\text { DC Currin and } \\
\text { HW Ittmann }\end{array}$ & $\begin{array}{l}\text { Council for Scientific and Industrial } \\
\text { Research }\end{array}$ & Multi-Product Allocation and Distribution \\
\hline 1986 & M Sinclair & University of Stellenbosch & $\begin{array}{l}\text { The Assignment of Workers to Tasks - An } \\
\text { Example from an Academic Department }\end{array}$ \\
\hline 1987 & KC Jordi & University of the Witwatersrand & $\begin{array}{l}\text { Interactive Multiple Objective Linear Pro- } \\
\text { gramming }\end{array}$ \\
\hline 1988 & M Sniedovich & $\begin{array}{l}\text { Council for Scientific and Industrial } \\
\text { Research }\end{array}$ & C-Programming \\
\hline 1989 & GJ Wessels & Colorado School of Mines, USA & $\begin{array}{l}\text { A Geometric Programming Algorithm for } \\
\text { solving a class of non-linear, signomial op- } \\
\text { timization problems }\end{array}$ \\
\hline 1990 & EC Dixon & Cambridge University, UK & $\begin{array}{l}\text { Modelling Under Uncertainty: Comparing } \\
\text { Three Acid-Rain Models }\end{array}$ \\
\hline 1991 & $\begin{array}{l}\mathrm{HC} \text { de Kock and } \\
\text { M Sinclair }\end{array}$ & Univeristy of Stellenbosch & $\begin{array}{l}\text { Three-level Decomposition Approach for } \\
\text { Solving Feedstock Problems on Microcom- } \\
\text { puters }\end{array}$ \\
\hline 1992 & $\begin{array}{l}\text { JW Hearne and } \mathrm{J} \\
\text { Swart }\end{array}$ & University of Natal & $\begin{array}{l}\text { Optimal translocation strategies for Saving } \\
\text { the Black Rhino }\end{array}$ \\
\hline 1993 & $\begin{array}{l}\text { G Erens, P } \\
\text { Salemink and CA } \\
\text { van der Merwe }\end{array}$ & University of South Africa & Regional Manpower Planning \\
\hline 1994 & $\mathrm{R}$ de Jongh & $\begin{array}{l}\text { PSI (part of Institute for Maritime } \\
\text { Technology (IMT)) }\end{array}$ & $\begin{array}{l}\text { Future: A Knowledge-Based System For } \\
\text { Threat Assessment (De Jongh et al. 1994) }\end{array}$ \\
\hline 1995 & TJ Stewart & University of Cape Town & $\begin{array}{l}\text { Contribution to MCDM over the past ten } \\
\text { years }\end{array}$ \\
\hline 1996 & $\begin{array}{l}\text { TJ Stewart and L } \\
\text { Scott }\end{array}$ & University of Cape Town & $\begin{array}{l}\text { A scenario-based framework for multicrite- } \\
\text { ria decision analysis in water resource plan- } \\
\text { ning }\end{array}$ \\
\hline 1997 & GJ Wessels & Deloitte \& Touche & $\begin{array}{l}\text { Guns or Butter: Decision Support for De- } \\
\text { termining the Size and Shape of the South } \\
\text { African Defense Force (Gryffenberg et al. } \\
\text { 1997) }\end{array}$ \\
\hline 1998 & T Stylianides & $\begin{array}{l}\text { Council for Scientific and Industrial } \\
\text { Research }\end{array}$ & A model of clinker capacity expansion \\
\hline 1999 & $\begin{array}{l}\mathrm{RC} \text { van den Hon- } \\
\text { ert }\end{array}$ & University of Cape Town & $\begin{array}{l}\text { Stochastic group preference modelling in } \\
\text { the multiplicative AHP: A model of group } \\
\text { consensus }\end{array}$ \\
\hline
\end{tabular}

Table 1: A list of TR medal recipients from 1971-1999. 


\begin{tabular}{|c|c|c|c|}
\hline Year & Recipient(s) & Institution & Title of paper/document \\
\hline 2000 & JW Hearne & University of Natal & $\begin{array}{l}\text { Compelling Reasons for Game Ranching in } \\
\text { Maputaland (Hearne \& McKenzie 2000) }\end{array}$ \\
\hline 2001 & $\begin{array}{l}\text { GE Huddlestone and JH } \\
\text { van Vuuren }\end{array}$ & $\begin{array}{l}\text { University of Stellen- } \\
\text { bosch }\end{array}$ & $\begin{array}{l}\text { Seeking Optimality in Fruit Pulping } \\
\text { Schedules: A Case Study }\end{array}$ \\
\hline 2002 & $\begin{array}{l}\text { G Groves, J le Roux and } \\
\text { JH van Vuuren }\end{array}$ & $\begin{array}{l}\text { University of Stellen- } \\
\text { bosch and University of } \\
\text { South Africa }\end{array}$ & Network service scheduling and routing \\
\hline 2003 & $\begin{array}{l}\text { RJ Fossati and JS } \\
\text { Wolvaardt }\end{array}$ & $\begin{array}{l}\text { Fugro Airborne and Uni- } \\
\text { versity of South Africa }\end{array}$ & $\begin{array}{l}\text { The Construction of Drape Surfaces with } \\
\text { Constrained First Derivatives }\end{array}$ \\
\hline 2004 & $\begin{array}{l}\text { SG Berjak and JW } \\
\text { Hearne }\end{array}$ & $\begin{array}{l}\text { University of } \begin{array}{r}\text { Stel- } \\
\text { lenbosch and RMIT, } \\
\text { Australia }\end{array}\end{array}$ & $\begin{array}{l}\text { Spatial Fire Modeling in Mkuze Game Re- } \\
\text { serve: A Case Study }\end{array}$ \\
\hline 2005 & FE van Dyk & $\begin{array}{l}\text { Council for Scientific and } \\
\text { Industrial Research }\end{array}$ & $\begin{array}{l}\text { An analysis of the South African fruit lo- } \\
\text { gistics infrastructure (Van Dyk \& Maspero } \\
2004 \text { ) }\end{array}$ \\
\hline 2006 & L Scott & University of Cape Town & $\begin{array}{l}\text { Unpacking developmental local govern- } \\
\text { ment using Soft Systems Methodology and } \\
\text { MCDA Tools }\end{array}$ \\
\hline 2007 & JM Greben & $\begin{array}{l}\text { Council for Scientific and } \\
\text { Industrial Research }\end{array}$ & $\begin{array}{l}\text { Model for Election Night Forecasting Ap- } \\
\text { plied to the } 2004 \text { South African Elections } \\
\text { (Greben et al. } 2006 \text { ) }\end{array}$ \\
\hline 2008 & $\begin{array}{l}\text { AP Burger, I Nieuwoudt } \\
\text { and JH van Vuuren }\end{array}$ & $\begin{array}{l}\text { University of Stellen- } \\
\text { bosch }\end{array}$ & $\begin{array}{l}\text { On the } \Delta(d) \text {-chromatic number of a com- } \\
\text { plete balanced multipartite graph }\end{array}$ \\
\hline 2009 & JH Nel & $\begin{array}{l}\text { University of Stellen- } \\
\text { bosch }\end{array}$ & $\begin{array}{l}\text { The identification of possible future } \\
\text { provincial boundaries for South Africa } \\
\text { based on an intramax analysis of journey- } \\
\text { to-work data (Nel et al. 2008) }\end{array}$ \\
\hline 2010 & $\begin{array}{l}\text { D Raad and JH van } \mathrm{Vu}^{-} \\
\text {uren }\end{array}$ & $\begin{array}{l}\text { University of Stellen- } \\
\text { bosch }\end{array}$ & $\begin{array}{l}\text { Robust multi-objective optimization for } \\
\text { water distribution system design using a } \\
\text { meta-heuristic (Raad et al. 2009) }\end{array}$ \\
\hline 2011 & $\begin{array}{l}\text { M Meyer, A van der } \\
\text { Merwe, G Streicher, J } \\
\text { Janse van Rensburg, J } \\
\text { Joubert and R Rossouw }\end{array}$ & $\begin{array}{l}\text { South Africa Synthetic } \\
\text { Oil Liquid }\end{array}$ & $\begin{array}{l}\text { Innovative Decision Support in a Petro- } \\
\text { chemical Production Environment (Meyer } \\
\text { et al. } 2011 \text { ) }\end{array}$ \\
\hline 2012 & I Durbach & University of Cape Town & $\begin{array}{l}\text { Modelling household responses to energy } \\
\text { efficiency interventions via system dynam- } \\
\text { ics and survey data (Davies \& Durbach } \\
2010 \text { ) }\end{array}$ \\
\hline
\end{tabular}

Table 2: A list of TR medal recipients from 2000-2012.

- the quality of any theory developed,

- interaction between theory and practice,

- new areas of application,

- new opportunities created for OR and

- clarity of exposition.

- Contributions should be in English.

\subsection{Paper classification}

\subsubsection{Institutions}

Figure 1 contains a summary of the institutions to which the winners were attached when they won the award. In the case where the winners of one paper were from two different 
institutions each institution receives half of the recognition.

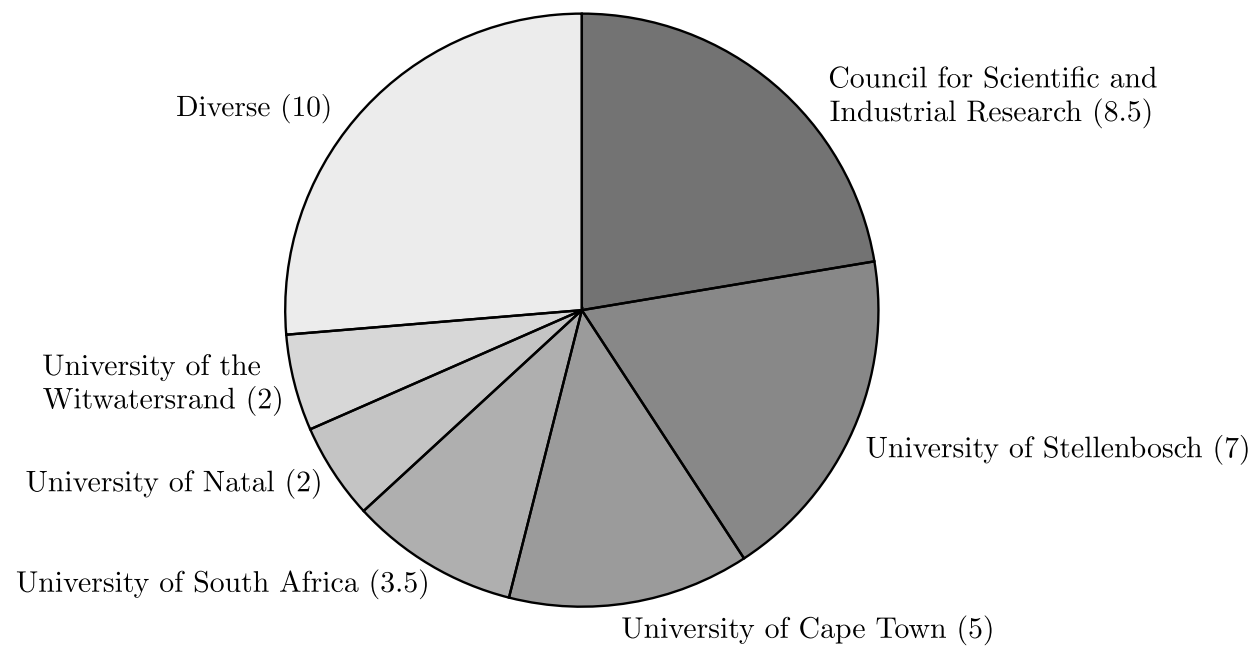

Figure 1: The TR medal winners categorized by institution.

Universities and the CSIR make up 32 out of the 38 of the award winning institutions. Under diverse there are a further four universities represented. Although these are typically research oriented institutions, most of the papers included are, in fact, more applied work and practically oriented which is where the main focus of OR lies in South Africa. UNISA, one of the first institutions were an OR department was established, has remained a large department both in terms of its staff complement and the number of OR students. One would have expected a better representation amongst the winners from this institution. Private sector hardly features with only CDM, Mobil Oil, PSI, Deloitte \& Touche and SASOL amongst the institutions while the Department of Posts and Telegraph and the South African National Defence Force represent government. Publishing is clearly not considered a priority in the private sector, while confidentiality is possibly also a factor in this regard. This does, however, not imply that OR is not practiced in business in South Africa. An added factor is that many analysts in private sector are practicing OR and they are not even aware of it.

\subsubsection{Journals within which papers were published}

Winning papers were published in a variety of both local and international journals. Table 3 gives a summary of these journals. (The number of publications listed is 40 in total because of the two articles apiece, in 1980 and 1984, by Stewart. On the other hand the C-programming reports of Sniedovich are considered as one.)

Any published paper that already went through a peer review process should therefore have a better chance of receiving the award. This certainly was the case before the rule was introduced that only published papers will be considered. It is to be expected that ORSSA members would prefer to publish in their own journal; nevertheless, 18 of the papers were published in international journals. All the journals in Table 3 are high quality journals with high standards. What is noticeable is that over the last ten years eight of the winning papers were published in ORiON. This is surely not indicative that 


\begin{tabular}{lc}
\hline Journal & Number \\
\hline ORiON & 12 \\
Computers and OR & 1 \\
Journal of the Operational Research Society (JORS) & 4 \\
Management Science & 1 \\
International Transactions in Operational Research (ITOR) & 2 \\
Ecological Modelling & 1 \\
Interfaces & 3 \\
Water Resources Research & 1 \\
European Journal of Operational Research (EJOR) & 2 \\
PhD's & 4 \\
Omega & 2 \\
Reports & 4 \\
Applied Mathematical Modelling & 1 \\
Book Chapters & 2 \\
\hline
\end{tabular}

Table 3: Journals within which winning papers were published.

ORSSA members only publish in ORiON. This may, however, indicate that mainly articles in ORiON are nominated for the award and that the net is not consciously cast wider or that papers in ORiON have been of higher quality in recent years. Members are invited to submit their papers but this does not always happen.

\subsubsection{Techniques used in the award winning publications}

As part of the analysis the various techniques used in each of the publications are shown in two groups, namely the more theory oriented papers and the applied or practically oriented publications. This allocation will possibly differ depending on who does the allocation. In Table 4 the techniques used in the research oriented publications are presented. It is clear that a variety of techniques is used and that the MCDM area is the only one where more extensive research is being done. Although this sample of research oriented TR papers is very small what is reflected in Table 4 is possibly a good representation of what happens in reality in the South African OR community.

\begin{tabular}{lc}
\hline Technique & Number \\
\hline Search Theory & 1 \\
Non-Linear Diff Eq./Sensitivity Analysis & 1 \\
MCDA & 3 \\
MOLP & 1 \\
Convex Programming & 1 \\
Geometric Programming & 1 \\
Linear Programming/Regression & 1 \\
Mineral Valuation & 1 \\
AHP & 1 \\
Graph Theory & 1 \\
\hline Total & 12 \\
\hline
\end{tabular}

Table 4: A summary of the research techniques used in winning papers.

Techniques used in the applied or practically oriented publications are given in Table 5 
together with the industry in which the technique was applied.

From Table 5 it may be seen that a wide variety of techniques were used for applied work. It is tempting to state that this is typical of applications in South Africa, but the sample is simply too small to make this claim categorically. The industry in which the applied work is being done also varies considerably. Given the fact that mining plays such a major role in the South African economy one would have expected more representation from this industry. OR presentations from this sector, at the annual ORSSA conference, started declining from the middle seventies as the industry started cutting costs which affected the OR departments within mines directly. This maybe one explanation for this seemingly lack of applied OR in mining. Government also does not really feature in Table 5 which is possibly a correct representation of current reality. However, no concrete conclusions can be drawn from these observations.

\begin{tabular}{llc}
\hline Technique & Industry & No. \\
\hline Dynamic Programming & Postal & 1 \\
Goal Programming & Agriculture & 1 \\
Integer Programming & Petroleum/Cement & 2 \\
Mixed Integer Programming & Mining/HR/Military & 3 \\
Linear Programming & Wild-Life/Water Res/Beverages/Agriculture & 4 \\
MCDM & Water Resources & 1 \\
Heuristics & Transport/Agriculture & 2 \\
Uncertainty Analysis & Environment & 1 \\
Non-Linear Differential Eq. & Wild-Life & 1 \\
Systems Modelling & HR/Energy & 2 \\
Cellular Automata Modelling & Environment & 1 \\
Simulation & Agriculture/Chemical & 2 \\
Soft Systems Methodology & Local Government & 1 \\
Optimal Smoothing & Energy & 1 \\
Intramax Method & Transport & 1 \\
Forecasting & Election & 1 \\
Expert Systems & Military & 1 \\
\hline Total & & 26 \\
\hline
\end{tabular}

Table 5: A summary of the techniques used in applied work published in winning papers.

\subsubsection{Individual winners}

The one person who stands out amongst the winners is Theodor J Stewart who has been awarded the TR medal on five occasions over the period selected for the analysis - twice jointly with co-authors. Stewart is one of the most prolific researchers in the OR field in South Africa. He initially worked in Search Theory but then started focussing on research in MCDA where he has contributed significantly in various capacities internationally (Köksalan et al. 2011). It is possibly not wrong to suggest that he should have been recognised for this theoretical work subsequent to 1995. In addition to this research, the winning papers with co-authors are of an applied nature illustrating his versatility.

The next most awarded person is Jan $\mathrm{H}$ van Vuuren who received it four times, jointly in all cases, and mostly with one of his students. Van Vuuren also has an impressive publication record. His research focus is on operations research, discrete mathematics, differential 
equations and cryptography. John W Hearne was the winner on three occasions mainly for work performed in the fields of wild-life conservation and the environment. This does indicate a characteristic of OR in South Africa in the sense that the OR community is relatively small resulting in individuals that work in a specific area. There are no large groups focussing on a particular area and this is evident from Table 5. The SASOL OR group is the exception and certainly currently the biggest OR group in South Africa. Finally, there is a small number of individuals who have received the award twice.

\subsection{Basic facts and application of rules}

There is no monetary reward attached to this award; recipients only receive a medal. Over the period of this analysis the medal was awarded on 38 occasions. There were nine papers where co-authors were not members of ORSSA. Seven females were recipients with no person of colour included amongst the list of recipients.

The gap of five years after the first award of the medal in 1971 is possibly due to the interpretation of the initial thinking that the medal should go to "a paper of most outstanding merit." There were presumably no papers of outstanding merit during those five years. During a meeting on 13 April 1976 the ORSSA Executive (ORSSA 1976) developed a set of rules and decided to make this an annual award.

The rules were not consistent over the years and were also applied differently. This would explain why certain awards were made that are not in line with the current rules. During the early years reports, mainly written reports as part of conference proceedings, and not peer reviewed journal articles were amongst the award-winning publications. These included Rudolph in 1971, Smith in 1976, Fatti in 1981, Lawton in 1983 and Sniedovich in 1988. In the case of Fatti (1983), the work was recognised in 1981 although a formal journal paper was only published in 1983 (the reference is to the journal article). The same holds for the paper of Stewart \& Ittmann (1979) — the TR medal was awarded to them in 1978.

The rules currently state explicitly that a paper must be in English to make it eligible. This rule also ensures a broader international audience. This was not a requirement initially. In this regard the papers by Wolvaardt (1979) and Bruwer (1982) were in Afrikaans and it turns out these two were the only two Afrikaans publications amongst all the recipients. It is also interesting to note that, because of this requirement, a very recent paper in ORiON, the first ever in Setswana (one of South Africa's eleven official languages) could not be taken into consideration for the award (Baitshenyetsi et al. 2011).

Amongst the list of recipients are four PhD theses, namely Wolvaardt 1979, Bruwer 1982, Jordi 1987 and Wessels 1989. This practice of considering PhDs for the award was discontinued since it was felt that allowing $\mathrm{PhD}$ theses possibly had an unfair advantage over other publications and, in addition, this $\mathrm{PhD}$ work should have been published in journals. A number of peer reviewed journal papers based on $\mathrm{PhD}$ work have received the TR medal namely that of Dixon (1990) and Fossati \& Wolvaardt (2003).

Another interesting fact is that Stewart in 1980, in 1984 and in 1995, as well as Sniedovich in 1988, where recipients of the award for their contributions to a specific field. In the case of Stewart it was initially for contributions to Search Theory after which it was twice 
for his extensive research contributions to the field of MCDA. In all these instances it was never specifically mentioned which contributions were considered and it is thus difficult to pinpoint which specific publication, report or journal article, or articles, were considered or were included within the contribution. For Stewart's contribution to Search Theory, two papers were considered namely Stewart (1979) and Stewart (1980). For the award in 1984 two papers are referenced here namely Stewart (1984a) and Stewart (1984b). It is generally accepted that the MCDA review paper, Stewart (1992), was the one used for the award in 1995 (Stewart 1999). In the latter case Stewart in fact did publish a number of papers on the MCDA topic in the ten-year period prior to receiving the award. In the case of Sniedovich the award was for C-Programming and it is assumed that there were only research reports available that were used to make this award. Some of the work might have been published later. Seven technical reports by Sniedovich are given in the reference list and all have C-Programming included as one of the keywords.

The current rule that only papers from the previous calendar year will be considered is an interesting one. Initially, when formal rules were defined for the award the rule was that only papers submitted up to 30th of September of a year prior to the annual conference i.e. only papers published from 1st October of the previous year till $30^{\text {th }}$ September of the current year, was to be considered (ORSSA 1976). It turns out that this rule was not always adhered too as illustrated by Currin \& Ittmann (1985) and Sinclair (1985), as well as, Stylianides (1998) and Van den Honert (1998). In both cases the respective papers were published in the same year and in the same edition of the same journal, but received their awards in successive years! There are a number of such examples where the rules were not applied consistently. Recently there was also an oversight in this regard. The award in 2011 went, very deservedly, to the SASOL team (Meyer et al. 2011). However, the paper was published in 2011 and should not have been considered for that years' award according to the rules. To correct this oversight it was decided to reconsider papers published in 2010 for the award. Justice was done in the sense that the best paper published in 2010 won the award in 2012. Given that the SASOL team was a finalist in the Franz Edelman competition it was highly unlikely that any other paper published in 2011 would have received the award, in the end it turned out fair and no paper was discriminated against.

\section{$3 \quad$ Award winning publications}

It would be impossible to present a detailed outline of each of the publications that led to the TR medal, but it is possibly of interest to provide a very brief summary to each of the award winning publications. In all cases the year in which the award was made is clearly indicated.

\subsection{Initial winners}

A longer summary for each of the first four papers is provided since they illustrate the innovative solution approaches developed, the impact the work had and the high standard of early OR practised in South Africa. One should also take into consideration that technology at that stage was nowhere near as sophisticated as it is today. 
TR 1971: Rudolph (1970) was the first recipient of the TR medal. Mail sorting constituted one of the major operations of the postal services of South Africa some forty years ago. It required approximately 4000 man-years of labour per annum. Any percentage improvement in sorting procedures would have resulted in a considerable absolute reduction of labour costs and a reduction of postal delays. The problem addressed was the following: Mail, in the form of letters or parcels, had to be sorted for dispatch or delivery to $n$ possible destinations. Equipment, either a sorting rack or a sorting machine, comprising $r$ sorting bins was to be used where $r<n$. What needed to be determined was in what manner and sequence the sorting bins should be allocated to single destinations and to groups of destinations in order to minimize sorting time or labour requirements. Previous mail sorting methods and policies were studied and it was realized that for an optimal mail sorting policy one cannot determine sorting rules in advance because these rules themselves depended on the mail distribution. This mail distribution should therefore be used for determining an optimal mail sorting policy. A dynamic programming approach was developed to solve this problem which led to considerable savings both in terms of time and labour.

TR 1976: Diamond mining off the Namibian (then South West African) coast was the context of the second winning publication (Smith 1975). The coastal mining deposits of South West Africa extended northwards from the mouth of the Orange River which was the southern border of this territory with South Africa. These deposits originated in inland kimberlites, released through erosion and transported to the coast by rivers. The diamonds were deposited along the coast for a considerable distance though the width of the deposit and the diamond size diminished with distance from the mouth of the river. These deposits were mined by Consolidated Diamond Mines (CDM) of South West Africa along a strike of about $100 \mathrm{~km}$. Given numerous constraints a medium term planning model was developed to determine optimal mining plans for each of the following five years. A mixed integer programing problem was formulated with approximately 7400 rows and 3900 columns and solved using a branch and bound algorithm.

TR 197\%: The Club of Rome initiated a study about the future of the planet in the sixties. This culminated in the publication of the book "Limits to Growth" (Meadows et al. 1972). The basic message conveyed in the results from the study was that of a catastrophe to the world. Vermeulen \& De Jongh (1976) initiated a study to investigate the sensitivity of the parameters used in this world model. They found that the mathematical model used in the "Limits to Growth" world model was very sensitive to very small parameter variations. One of their results showed that by changing three parameters by $10 \%$ each the world population collapse as predicted by the model could already be averted by the year 1975 !

TR 1978: In their short history of the early years of ORSSA Geldenhuys \& Rudolph (1999) makes reference to one of the first large projects the CSIR had to execute for the South African Maize Board, concerning the distribution of maize in the country. This was a typical transportation model that was solved using linear programming. A complication of the solution was that, although the solution was optimal, the costs allocated to demand points, especially those close to each other, were not equitable. This was initially corrected using a logical/heuristic approach. Using the fact that the optimal solution was degener- 
ate, Stewart \& Ittmann (1979) formulated a second phase as a goal programming model without losing optimality but obtaining much more equitable solutions. They were the fourth winners of the TR medal, and their paper illustrates an ingenious and innovative approach to solving a difficult problem. The Maize Board used this transportation model at least twice a year until deregulation in the nineties.

\subsection{Brief summaries for the rest of award winning work}

Brief summaries are provided of the various publications and papers. The summaries are classified in terms of techniques or application areas.

\section{Search theory}

TR 1980: In the paper by Stewart (1979) algorithms were developed for optimizing searcher motion in cases involving the solution of search problems where resources cannot instantaneously be re-located, but searchers are constrained to follow defined tracks at speeds which are slow compared to detection times. Stewart (1980) reports on computational experience with the branch-and-bound algorithm proposed for determining a track for a single searcher while searching a moving target in discrete time and space. In addition a heuristic adaptation is proposed for use when there are multiple searchers.

\section{MCDA}

TR 1984: In Stewart (1984a) a method was proposed for MCDA problems in an interactive environment, when decision-maker preferences are inconsistent with a simple utility model and/or are self-inconsistent. Stewart (1984b) demonstrated that much stronger evaluations of preference are possible by applying formal statistical inferential procedures to a simple parametric model, relating indifference to closeness on a scale defined by a linear function of attribute values.

TR 198\%: The specific case of linear programming problems with multiple objectives was considered by Jordi (1985). A new method of utilising indifference trade-off information which is given by a decision-maker was proposed. The resulting estimated marginal utility vector was then used in two interactive algorithms.

TR 1995: This paper (Stewart 1992) sought to review and to contrast the main streams of thought in MCDA theory and practice, without attempting to review all MCDA methods in detail. The main purpose was to identify pitfalls in the usage of various approaches and to suggest approaches which are most robustly and effectively used, especially by the non-expert in MCDA methodology.

TR 1999: A group of preference models was proposed by Van den Honert (1998) for the representation of a group decision making process under the multiplicative variant of the Analytic Hierarchy Process.

\section{Diverse techniques}

TR 1988: C-programming, a method for solving different types of non-linear optimization problems was introduced. It was shown that problems of this type can be solved by considering a proxy problem of a Lagrangian form. The method can extend the scope of standard optimization techniques such as the linear and integer programming methods 
(Sniedovich 1984, 1986a, 1986b, 1986c, 1986d, 1986e, 1986f).

TR 1989: A new algorithm was presented (Wessels 1989) for solving a large class of nonlinear constrained optimisation problems with several degrees of complexity. The rationale behind the research was to enlarge the class of nonlinear optimisation problems that can be solved by the use of geometric programming.

$T R$ 2008: The problem of finding the minimum number of colours with which the vertices of a complete, balanced, multipartite graph $G$ may be coloured such that the maximum degrees of all colour class induced subgraphs are at most some specified integer $d \in \mathbb{N}$ was addressed by Burger et al. (2007).

\section{Industry}

$T R$ 1981: The tariff structure of a gas producer was designed in such a way that it encouraged users to achieve as smooth a demand for gas as possible. The paper (Fatti 1983) discusses optimal smoothing of gas utilisation where on the one hand the only control variables are maximum hourly and daily flow rates, and on the other hand gas storage tanks can be erected to assist in smoothing the demand.

$T R$ 1983: Mobil Oil markets a group of products. The cost of the product components change in discrete steps depending on the amount purchased. Thus, if a volume between 0 and $V_{1}$ is purchased, the price will be $x$ per unit while if $V_{1}-V_{2}$ is purchased, the price will be $y(y<x)$. In addition, the suppliers sometimes offer discounts ranging from 1$5 \%$, depending on the total amount purchased from the supplier. These again are usually in discrete steps. The problem was formulated (Lawton 1982) as a large-scale integer programming (IP) problem which also involves subjective managerial preferences.

TR 1985: An interactive decision support system was developed for South African Breweries (SAB) to optimize the allocation and distribution of beer (Currin \& Ittmann 1985). The model considered the brewing, packaging and distribution of beer with the aim to minimize total costs. A two-phase model was developed that allowed considering future sales, decomposing the problem into a large number of sub-problems (to reduce solution time) and the equitable distribution of products to the depots when stocks are over- or undersupplied.

TR 1998: A cement manufacturer was confronted with capacity expansion over a long-term capital planning horizon and needed to determine an optimal plan for clinker expansion. The model was implemented using a mixed integer programming model as a decision support system by Stylianides (1998).

\section{Water resources}

$T R$ 1996: A new framework for MCDA and group negotiation support, incorporating many of the tools and concepts of MCDA and of "decision conferencing," is described in Stewart \& Scott (1995) for use in water resources planning at a strategic level.

TR 2010: The design of an urban water distribution system (WDS) is a challenging problem involving multiple objectives. In this case (Raad et al. 2009) the goal was to find the set of solutions which embodies an acceptable trade-off between system cost and reliability, so that the ideal solution may be selected for a given budget. A metaheuristic algorithm is applied to a WDS design. It uses multiple metaheuristics simultaneously 
in an attempt to improve optimization performance. Large cost savings and reliability improvements were demonstrated.

\section{Environmental problems}

TR 1990: Three themes of modelling were examined, the primary concern being representing uncertainty in models, while the issue of interactive computer modelling and the use of models as decision aids were also considered. These issues were addressed by way of a comparative analysis of three models of the acid-deposition problem which had been developed at that stage in the UK and USA (Dixon 1989).

TR 1992: A non-linear differential equation model for a population of black rhino was developed by Hearne \& Swart (1991) to assist in developing optimal translocation strategies to enhance the survival prospects of this species. Various simulations were performed to determine the number and age of the species that should be trans-located to maximize the growth rate.

TR 2000: Considerable land is being devoted to wildlife in South Africa with the ultimate aim of game ranching. This has become economically attractive for landowners, especially in Maputaland. Large sums of initial capital are required for the acquisition of game, the creation of fences and other infrastructure. In this book chapter Hearne \& McKenzie (2000) presents four case studies outlining how this problem was addressed.

TR 2004: Controlled burning is a necessary and regular activity in the Mkuze Game Reserve. Predicting the rate and extent of fire spread in controlled burning operations is, therefore, an important management objective. A cellular automaton model developed by Berjak \& Hearne (2002) for fire spread was evaluated in terms of this objective using empirical data for two case studies in Mkuze Game Reserve.

\section{Agriculture}

TR 1991: A three-level decomposition algorithm was developed which substantially improved the solution times for feedstock linear programming problems. A new approach to the decision problem where new raw material or extra quantities of existing raw material are added, based on the results of the three-level decomposition algorithm, was presented in De Kock \& Sinclair (1990).

TR 2001: Decisions regarding the process of scheduling fruit pulping for the production of fruit juices include processing time, the disposal of the fruit that will not be pulped before stock loss due to spoilage, the fulfilment of customer demand and an optimal financial position. A mathematical model, taking these and other constraints into consideration, was developed (Huddlestone \& Van Vuuren 1999) which enabled the construction of a pulping strategy minimising cascading financial losses associated with fruit grade drops within the stock pile.

$T R$ 2005: Given the increasing production and export volumes, development of new markets for the South African fruit industry together with the shortage of logistics infrastructure capacity during peak seasons, the paper by Van Dyk \& Maspero (2004) describes an investigation into the optimal usage of existing infrastructure on a national level making recommendations with regard to the development of additional infrastructure.

\section{Local government}


TR 2006: Two different analytical approaches, i.e. Soft Systems Methodology (SSM) and Multi-Criteria Decision Analysis (MCDA), that may be useful in developing an understanding of developmental local government (DLG) was presented and described by Scott (2005).

\section{Diverse}

TR 1979: Wolvaardt (1978) developed a theory, using a mineral valuation approach that can be applied to quantify the supply and extraction of coal that is so indispensable for the generation of electricity in South Africa.

TR 1982: Information as a strategic resource is becoming increasingly important for organisations. In this study by Bruwer (1981) a statistically oriented conceptual model of a management information system was developed to assist the developers of MISs to ensure the provision of accurate information for different levels of management and to satisfy external information needs.

TR 1986: In Sinclair (1985) a description was given of the application of OR techniques to the problem of assigning lecturers to tasks in an academic department.

TR 1993: A methodology for regional manpower planning was designed (Erens et al. 1992) to accommodate the full range of problems encountered by applying a systems approach which is based on the discipline of operations research and strategic planning.

TR 1994: A knowledge-based decision support system, called Future, was developed by De Jongh et al. (1994) for the South African Navy intelligence unit to help in the monitoring of shipping movements worldwide and to identify any possible threatening event as early as possible.

TR 2002: A graph theoretic heuristic approach was presented to determine an efficient service route for a single service vehicle through a transportation network that requires a subset of its edges to be serviced, each a specified (potentially different) number of times (Groves et al. 2004).

TR 2003: Airborne geophysical surveys are conducted at very low altitude within the performance limits of the aircraft used. Uneven ground surfaces make it almost impossible for pilots to fly at a constant height above ground. A drape surface needs to be constructed within the aircraft's performance parameters before a flight. An LP was formulated (Fossati \& Wolvaardt 2001) with constraints at every point of a grid covering the area concerned.

TR 200\%: A novel model and approach was developed to predict the outcome of elections, both at national and local level utilising the availability of early results. The forecasting model has been used very successfully in a number of elections (Greben et al. 2006).

TR 2009: National census data contain information on place of residence and place of work. Utilising these data, the intramax method can determine journey-to-work flows. From these flows interesting applications, such as the demarcation of regions in South Africa and solutions to disputed areas can be determined. The paper by Nel et al. (2008) also showed how this method can be used to propose new boundaries for four or five new provinces. 
TR 2012: An application of building a system dynamics model of the way households might respond to interventions aimed at reducing energy consumption specifically the use of electricity) was described in this paper by Davies \& Durbach (2010).

\section{Additional recognition}

\subsection{Franz Edelman award}

The work of operations researchers in South Africa has also received recognition internationally. On two occasions South African entries were amongst the six/seven finalists in the most prestige Franz Edelman competition of INFORMS, the OR society of the USA. In 1996 the entry from the South Africa National Defence Force (SANDF) won the award while in 2010, SASOL, was one the finalists, coming very close to winning the award.

INFORMS describes this competition as follows: "The Franz Edelman competition attests to the contributions of operations research and analytics in both the profit and non-profit sectors. Since its inception, cumulative benefits from Edelman finalist projects have topped the $\$ 180$ billion mark. Edelman finalist teams have improved organizational efficiency, increased profits, brought better products to consumers, helped foster peace negotiations, and saved lives. The purpose of the Franz Edelman competition is to bring forward, recognize and reward outstanding examples of operations research, management science and advanced analytics in practice in the world." (INFORMS 2013b)

Franz Edelman Winner 1996 and TR 199\%: After the establishment of a full democracy in 1994 the Government of National Unity in South Africa launched a massive Reconstruction and Development Program (RDP). This inevitably led to the reprioritization of scare and limited resources. It was against this background that the SANDF had to re-plan. Planners in the SANDF were confronted with the following question (Gryffenberg et al. 1997): "How does the SANDF decide, in the absence of a major conventional military threat and with a limited budget, what its size and shape should be, and what main equipment is required?" Project Optimum was launched with a fair bit of scepticism within the SANDF itself (Thiart 1996). Using a mixed integer programming approach the project team developed a decision support model for force structuring of the SANDF. To have won the Franz Edelman award was a major accomplishment for the project team but also a feather in the cap for the OR fraternity in South Africa. The submission to the Franz Edelman committee included a letter from the then President of the country, $\mathrm{Mr}$ Nelson Mandela. One can only speculate whether this letter, by a world icon, might have influenced the thinking of the panel of judges! The letter is reproduced, unaltered, in full below:

Introduction by Pres Nelson Mandela to presentation for the Franz Edelmann competition:

Chairperson: Members of the Institute for Operations Research and the Management Sciences; ladies and gentlemen.

It is indeed a privilege to address you in Washington from sunny South Africa. My message, brief as it may be, serves merely to convey to you the high regard 
which we in South Africa have for all the members of our new national Defence Force. Let me assure you that the historic changes in our country would not have been possible without the loyalty and professionalism of our men and women in the armed forces.

We are committed to maintain and strengthen this vital national asset, the severe resource limitations notwithstanding. To this end, the National Defence Force, on its own initiative, has demonstrated its commitment to the nation by a highly professional application of modern management science and operations research techniques. As such, it is even better placed to provide adequate, appropriate and affordable defence for our new democratic Republic, now and beyond the year 2000.

I am proud of them and grateful for their initiative and valuable contribution. Allow me to wish the South African National Defence Force team good luck in their endeavours in Washington.

To everyone involved in the Franz Edelmann competition, I send my warmest greetings and those of all my fellow South Africans. Be assured of our highest esteem. I wish you a pleasant conference.

Nelson Mandela, President, Republic of South Africa, 22 April 1996.

Franz Edelman Finalist 2010 and TR 2011: The Simulation and Modelling team of SASOL was the second South African team to be finalists in the Franz Edelman competition (Meyer et al. 2011). From very humble beginnings, in the nineties, the group has grown substantially and has earned significant credibility in the company. Most people in South Africa know that SASOL leads the world in producing liquid fuels from natural gas and coal. In this regard SASOL faces many challenges, namely stricter fuel specifications, fluctuating oil and gas prices, all within a developing-world context. In the past, the petrochemical industry based its business decisions on average production limits. A better approach to understand and include the effect of variability and dynamics in its decision making process was desperately needed. The modelling operations using stochastic simulation (MOSS) methodology was developed to address this deficiency. MOSS is an application of OR that has helped to radically improve decision making. For many years SASOL has now been using this methodology to build discrete-event simulation models. The models have continuously proven their value by enhancing insights, enabling collaboration, ensuring efficient and effective production. In addition it has had a major positive effect financially. This work has further applications in the wider chemical and fuels industries. SASOL is indeed an exemplary example of the impact OR can make.

\subsection{Goodeve medal}

Further international recognition was awarded for the paper by Fatti (1983) for which he received the Goodeve medal from the Operational Research Society of the United Kingdom. The medal is for a paper published in one of the two journals of that society during the previous year. 


\subsection{IFORS prize for OR in development}

At the triennial conference of the International Federation of Operational Research Societies (IFORS) the IFORS Prize for OR in Development is awarded to qualifying papers. These papers are evaluated on a number of criteria, namely problem definition, creativity and appropriateness of approach. Typically only eight papers are accepted for presentation at the conference after an initial screening. On three occasions, namely in 1999 at the $15^{\text {th }}$ IFORS conference held in China (Van Vuuren \& Gründlingh 2001), in 2002 at the $16^{\text {th }}$ IFORS conference in Scotland (Groves et al. 2004) and in 2008 at the $18^{\text {th }}$ IFORS conference in South Africa (Raad et al. 2009), papers from ORSSA members were runners-up for this prize. Two of these papers (Groves et al. 2004 and Raad et al. 2009) subsequently won the TR medal.

\subsection{EURO excellence in practice award}

The paper by Stylianides (1998) was the runner-up for the EURO Excellence in Practice Award (EEPA). This paper was presented at the joint EURO XV/INFORMS XXXIV conference that was held in Barcelona, Spain in July 1997.

\subsection{South African Presidency}

The paper by Nel et al. (2008) addresses an important national issue in South Africa, namely spatial development from a transport point of view. Their paper specifically addresses provincial boundaries in the country. The authors were invited to present their work to the South African Presidency.

\section{Conclusions}

This paper endeavours to document various aspects around the TR medal, and the recipients, over the period of the analysis. The rules are such that there is a high probability that very good papers were not recognised in this way since the medal can only be awarded to a paper for a specific calendar year. Nevertheless, although the sample of publications is relatively small, the following can be concluded:

- Papers were published in a variety of journals, both local and international. It is encouraging that OR work from South Africa can compare with what is published elsewhere in the world.

- There are more applied papers than theory oriented publications which does reflect reality, at least, within the OR community as represented by members of ORSSA.

- The private sector is not highly visible and it illustrates that to publish is not a priority in this sector, while confidentiality remains a problem and contributes to this problem.

- Most of the award-winning publications are from either universities or the CSIR, even applied work is forthcoming from these institutions.

- A wide range of different techniques were used, but the application of linear programming and related techniques stand out. 
- There is no industry that stands out and this implies that the winning publication represents a diverse range of sectors.

- The highest number of times one individual won is five in the person of Theodor J Stewart, the next two highest winners received the medal four and three times, respectively.

- For a relatively small society it has been an achievement to have produced two Franz Edelman finalists of which one won the award. A number of other recognitions, internationally and locally, were received as well. There are not many amongst the 50 plus international OR societies that can claim this.

- Although this paper certainly gives a view on the practice of OR in South Africa, it is very difficult to point towards any trends as such.

- All the papers and publications included under the TR medal recipients are outstanding and reflect what was originally envisaged for this award, namely originality, quality of theory developed, interaction between theory and practice, and clarity of exposition.

All efforts were made to ensure that the facts, etc. in this paper are correct, yet there is no guarantee around this because of the lack of proper record keeping, etc. especially during the early years of ORSSA. Nevertheless proper recording of the history of this society remains an important component in the life of the society. It is hoped that this paper goes some way into achieving this.

\section{References}

[1] Baitshenyetsi LT, Kruger HA \& Hattingh JM, 2011, Tiragatso Ya Itlhagiso Ya Sethare Se Se Okeditsweng Ka Kgetsi Mo Bothateng Jwa Popo Ya Metato Ya Dipeipi Tsa Oli, ORiON, 27(2), pp. 101-117.

[2] Berjak SG \& Hearne JW, 2002, Spatial fire modeling in Mkuze Game Reserve: A case study, ORiON, 18(1,2), pp. 37-57.

[3] Bruwer PJS, 1981, Bydraes tot Modelontwikkeling ten einde gerekenariseerde stelsels se werkverrigting te evalueer, PhD Thesis, North-West University, Potchefstroom.

[4] Burger AP, Nieuwoudt I \& Van Vuuren JH, 2007, On the $\Delta(d)$-chromatic number of a complete balanced multipartite graph, ORiON, 23(1), pp. 29-49.

[5] Currin DC \& Ittmann HW, 1985, Multi-product allocation and distribution, ORiON, 1(2), pp. 7082.

[6] Davis S \& Durbach I, 2010, Modelling household responses to energy efficiency interventions via system dynamics and survey data, ORiON, 26(2), pp.79-96.

[7] De Jongh PJ, Carden KJ \& Rogers NA, 1994, Future: A knowledge-based system for threat assessment, Interfaces, 24(2), pp. 76-86.

[8] De Kock HC \& Sinclair M, 1990, Three-level decomposition approach for solving feedstock problems on microcomputers, Journal of the Operational Research Society, 41(7), pp. 561-571.

[9] Dixon EC, 1989, Modelling under uncertainty: Comparing three acid-rain models, Journal of the Operational Research Society, 40(1), pp. 29-40.

[10] Erens G, Salemink P \& Van der Merwe CA, 1992, Regional manpower planning, ORiON, 8(1), pp. 33-53.

[11] FATTI LP, 1983, Optimal smoothing of demand for industrial gas, Journal of the Operational Research Society, 34(7), pp. 583-590. 
[12] FatTi LP, 1988, Current practice of Operational Research/Management Science in South Africa, Omega, 16(3), pp. 181-187.

[13] Fossati RJ \& WolvaARdT JS, 2001, The construction of drape surfaces with constrained first derivatives, ORiON, 17(1,2), pp. 65-80.

[14] Geldenhuys G \& Rudolph G, 1999, A brief history of the beginnings of Operations Research in South Africa, [Online], [Cited January $2^{\text {nd }} 2013$ ], Available from www.orssa.org.za.

[15] Greben JM, Elphinstone C \& Holloway J, 2006, A model for election night forecasting applied to the 2004 South African elections, ORiON, 22(1), pp. 89-103.

[16] Groves G, Le Roux J \& Van Vuuren JH, 2004, Network service scheduling and routing, International Transactions in Operational Research, 11(6), pp. 613-643.

[17] Gryffenberg I, Lausberg JL, Smit WJ, Uys S, Botha S, Hofmeyr FR, Nicolay RP, Van Der Merwe WL \& Wessels GJ, 1997, Guns or butter: Decision support for determining the size and shape of the South African national defense force, Interfaces, 27(1), pp. 7-28.

[18] Hearne JW, 1994, African OR adventure, ORMS Today, December, pp. 50-53.

[19] Hearne JW, 1999, Hunting for profits, ORMS Today, April, pp. 40-43.

[20] Hearne JW \& McKenzie M, 2000, Compelling reasons for game ranching in Maputaland, pp. 417438, in Prins HHT, Grootenhuis JG \& Dolan TT (Eds), Wildlife conservation by sustainable use, Conservation Biology Series, Kluwer Academic Publishers, London.

[21] Hearne JW \& Swart J, 1991, Optimal translocation strategies for saving the Black Rhino, Ecological Modelling, 59(3,4), pp. 279-292.

[22] Huddlestone GE \&JH van Vuuren, 1999, Seeking optimality in fruit pulping schedules: A case study, ORiON, 15(1,2), pp. 25-51.

[23] INFORMS, 2013a, [Online], [Cited January 2 ${ }^{\text {nd }}$ 2013], Available from http://www.informs.org/ Recognize-Excellence/INFORMS-Prizes-Awards.

[24] INFORMS, 2013b, [Online], [Cited January 2 ${ }^{\text {nd }}$ 2013], Available from http://www.informs.org/ Recognize-Excellence/Franz-Edelman-Award.

[25] Ittmann HW \& Yadavalli VSS, 2010, The Operations Research Society of South Africa, in Cochran JJ (ED), Wiley Encyclopaedia of Operations Research and Management Science, John Wiley \& Sons, Hoboken (NJ).

[26] JoRd KC, 1985, Interactive multiple objective linear programming, PhD Thesis, University of the Witwatersrand, Johannesburg.

[27] Köksalan M, Wallenius J \& Zionts S, 2011, Multiple Criteria Decision Making - From early history to the $21^{\text {st }}$ Century, World Scientific Publishing, Singapore.

[28] Lawton JC, 1982, A purchasing problem, Proceedings of the $13^{\text {th }}$ Annual Conference of the Operations Research Society of South Africa, Rustenburg, pp. 1-15.

[29] Meadows DH, Meadows DL, Randers J \& Behrens WW, 1972, The limits to growth, Potomac Associates/Universe Books, New York (NY).

[30] Meyer M, Robinson H, Fisher M, Van der Merwe A, Streicher G, Janse van Rensburg J, Van den Berg H, Dreyer E, Joubert J, Bonthuys G, Rossouw R, Louw W, Van DevenTER L, WYKES CL \& CAWOOD E, 2011, Innovative decision support in a petrochemical production environment, Interfaces, 41(1), pp. 79-92.

[31] Nel JH, Krygsman SC \& De Jong T, 2008, The identification of possible future provincial boundaries for South Africa based on an intramax analysis of journey-to-work data, ORiON, 24(2), pp. 131156.

[32] OR Society, 2013, [Online], [Cited January 2 ${ }^{\text {nd }}$ 2013], Available from http://www.theorsociety. com/Pages/Awards/Goodeve. aspx.

[33] ORSSA, 1971, Obituary: Tom Rozwadowski, ORSSA Newsletter, June, pp. 23-26.

[34] ORSSA, 1976, ONSA Toekennings, ORSSA Newsletter, June, pp 5-7. 
[35] ORSSA, 2013, [Online], [Cited January $2^{\text {nd }}$ 2013], Available from http://www.orssa.org.za/wiki/ pmwiki.php?n=Awards. TomRozwadowskiMedal.

[36] RaAd D, Sinske A \& Van Vuuren JH, 2009, Robust multi-objective optimization for water distribution system design using a meta-metaheuristic, International Transactions in Operational Research, 16(5), pp. 595-626.

[37] Rudolph GJ, 1971, Optimal mail sorting policy, ORSSA Newsletter, June, pp. 29-40.

[38] ScOtт L, 2005, Unpacking developmental local government using soft systems methodology and MCDA, ORiON, 21(2), pp. 173-195.

[39] Sinclair M, 1985, The assignment of workers to tasks - An example from an academic department, ORiON, 1(2), pp. 49-69.

[40] Sмiтн BJK, 1975, A medium term mine planning system for a beach diamond deposit, Proceedings of the Annual Conference of the Operations Research Society of South Africa, Johannesburg, pp. 1-9.

[41] Sniedovich M, 1984, C-programming: A method for solving a class of non-linear optimization problems, (Unpublished) Technical Report TWISK 354, CSIR, Pretoria.

[42] Sniedovich M, 1986a, C-programming and the minimization of pseudoconcave functions, (Unpublished) Technical Report TWISK 437, CSIR, Pretoria.

[43] Sniedovich M, 1986b, Using dynamic programming in solving non-separable water resources problems, (Unpublished) Technical Report TWISK 451, CSIR, Pretoria.

[44] Sniedovich M, 1986c, On the maximization of generalized convex functions, (Unpublished) Technical Report TWISK 452, CSIR, Pretoria.

[45] Sniedovich M, 1986d, C-programming and maximal mean-standard deviation ratio problems, (Unpublished) Technical Report TWISK 457, CSIR, Pretoria.

[46] Sniedovich M, 1986e, Fractional programming revisited, (Unpublished) Technical Report TWISK 459, CSIR, Pretoria.

[47] Sniedovich M, 1986f, Analysis of a class of fractional programming problems, (Unpublished) Technical Report TWISK 463, CSIR, Pretoria.

[48] Stewart TJ, 1979, Search for a moving target when searcher motion is restricted, Computers and Operations Research, 6(3), pp. 129-140.

[49] Stewart TJ, 1979, Experience with a branch-and-bound algorithm for constrained searcher motion, pp. 247-253 in Haley KB \& Stone LD (Eds), Search Theory and Applications, Plenum Publishers, New York (NY).

[50] StewaRt TJ, 1984a, Inferring preferences in multiple criteria decision analysis using a logistic regression model, Management Science, 30(9), pp. 1067-1077.

[51] StewART TJ, 1984b, The inferring of preferences from indifferences in multicriteria decision analysis, OMEGA, 12(2), pp. 1175-184.

[52] Stewart TJ, 1992, A critical survey on the status of multiple criteria decision making theory and practice, OMEGA, 20(5,6), pp. 569-586.

[53] Stewart TJ, 1995, OR practice in South Africa, European Journal of Operational Research, 87(3), pp. $464-468$.

[54] Stewart TJ, 1999, ORSSA-TR medal, [Personal Communication], Contactable at theodor.stewart@ uct.ac.za.

[55] Stewart TJ \& ItTmann HW, 1979, Two-stage optimization in a transportation problem, Journal of the Operational Research Society, 30(10), pp. 897-904.

[56] Stewart TJ \& Scott L, 1995, A scenario-based framework for multicriteria decision analysis in water resources planning, Water Resources Research, 31(11), pp. 2835-2843.

[57] Stylianides T, 1998, A model of clinker capacity expansion, European Journal of Operational Research, 110(2), pp. 215-222.

[58] Thiart G, 1996, Fellow South Africans..., SALUT, July, pp. 12-14. 
[59] VAn Den Honert RC, 1998, Stochastic group preference modelling in the multiplicative AHP: A model of group consensus, European Journal of Operational Research, 110(1), pp. 99-111.

[60] Van Dyk FE \& Maspero E, 2004, An analysis of the South African fruit logistics infrastructure, ORiON, 20(1), pp. 55-72.

[61] VAN VUUREN JH \& GRÜNDLINGH WR, 2001, An active decision support system for optimality in open air reservoir release strategies, International Transactions in Operational Research, 8(1), pp. 439-464.

[62] Vermeulen PJ \& De Jongh DCJ, 1976, Parameter sensitivity of the 'Limits to Growth' world model, Applied Mathematical Modelling, 1(1), pp. 29-32.

[63] Wessels GJ, 1989, A geometric programming algorithm for solving a class of nonlinear, signomial optimization problems, PhD Thesis, Colorado School of Mines, Denver (CO).

[64] WolvaArdt JS, 1978, 'n Teorie van die aanbod van steenkool, PhD Thesis, University of South Africa, Pretoria. 